Volume 5 No I

Tahun 2022
ISSN 2614-2775 (Print)

ISSN 2621-8143 (Online)

\title{
THE FOOTBALL PASSING TECHNIQUE SKILLS
}

\author{
Vega Soniawan', Yogi Setiawan², Eval Edmizal ${ }^{3}$, \\ Jeki Haryanto ${ }^{4}$, Ikhwanul Arifan ${ }^{5}$ \\ Universitas Negeri Padang 1,2,3,4,5 \\ vegasoniawan@fik.unp.ac.id
}

\begin{abstract}
This research is conducted due to the problems in football, where some players tend to do wrong passing, inaccurate passing, and lack of passing power and quality. The research aims to describe the football passing technique skills in using the inside of the foot in terms of movement quality (preparation phase, impact phase, and follow-through) and result quantity of the football passing skills. The subjects were 30 football players from UNP Football Club. The data collection was conducted through video observation assessed by the football experts and using the football short passing test instrument. Based on the data analysis, it is found that the average of about 10.13 (80.28\%) in terms of movement was also categorized as sufficient. Thus, the football coaches in UNP Football Club can improve the football passing technique regarding movement quality and result quantity in each football exercise process.
\end{abstract}

Keywords: The Football; Passing Technique Skills

Accepted: $07^{\text {th }}$ of Januari 2022

Correspondence author: Vega Soniawan, Universitas Negeri Padang. E-Mail: vegasoniawan@fik.unp.ac.id DOI http://dx.doi.org/10.31851/hon.v5i1.6503 ${ }^{\text {doi }}$

\section{(c) (i) (2)}

Jurnal Halaman Olahraga Nusantara licensed under a Creative Commons Attribution-ShareAlike 4.0 International $\underline{\text { License }}$

\section{INTRODUCTION}

Football has developed over the years because it is not only played by men but also by women who are already involved in the game of football. It can be seen from the number of people who love football both as spectators and as players of the game it self (Aminudin et al., 2020). This development does not only occur in urban areas but also the rural areas (Gema et al., 2016). Another phenomenon is also marked by the increase in associations or football clubs, football academies, training centers, extracurriculars that are fostered in an organized manner, which is expected to produce 
Jendral A. Yani Street Lorong Gotong Royong 9/10 Ulu Palembang South Sumatera

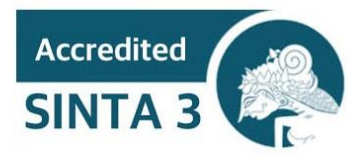

email jurnal: jurnalhon@univpgri-palembang.ac.id situs web: http://www.univpgri-palembang.ac.id

quality football players who can support exemplary achievements in clubs so that they can represent Indonesia on the national and international arena (Asrul et al., 2021).

This development needs to be followed up with regular, directed, and planned development efforts systematically and sustainably. It will build reliable players so that they can become good players in the future, the pupose of the planed exercise are to create a good physical conditioning so that they are ready to compete (Pandaleke et al., 2019; Haryanto \& Welis, 2019). Football is a game that requires a lot of energy and intelligence on the field because it can spur enthusiasm while providing joy through togetherness in a team (Syukur \& Soniawan, 2015). The purpose of football is a game played by kicking the ball the players to get the ball into the opponent's goal (Ridlo, Azi Faiz \& Saifulloh, 2018); Anwar et al., 2019). Football is a team game, which consists of eleven players with each team consisting of goalkeepers, defenders, midfielders and forwards. Football is a sport that is quite popular and is played in groups (Asrul et al., 2021)

PSSI is a football association in Indonesia that has created a multilevel competition platform for football players to improve players' abilities. The development of achievements in football in stages and continuously has implications for the importance of evaluation which must be carried out periodically from the athlete screening stage to the final stage of implementing the training program and the achievements achieved (J. Arwandi, M. Ridwan, R. Irawan, \& Soniawan, 2020).

In improving the performance of athletes in playing football, many factors must be considered. Some factors affect football performance, such as physical, technical, tactical, and mental conditions (Soniawan, V,. \& Irawan, 2018). These factors are interrelated in achieving the desired performance. If there is only one element that the player does not achieve, he cannot become a good player (Trianda, M., Maidarman, M., Mardela, R., \& Soniawan, 2020). 
To improve the quality of the game towards achievement, technical problems are one of the conditions for determining achievement (Aguiar et al., 2012). Playing football requires a good mastery of football techniques because playing technical skills supports a player (Almeida et al., 2013). Players who have football technical skills will play in various situations, thus providing convenience in applying tactics and creating good cooperation in groups and teams to achieve victory (Meylan et al., 2014). Thus, through good and well-planned coaching and program development, good techniques will be obtained. Good technique is described in the form of a skilled human figure in playing football.

The technique is a fundamental thing that all players must master in order to play football skillfully. Aspects of training that need to be developed in early childhood are especially correct technical skills and improvement of physical condition (Soniawan et al., 2021). Therefore, every coach must understand the stages of training from this aspect of the exercise so that they know the portion of training for multilateral and specialization. Techniques in football are passing the ball, kicking the ball towards the goal (shooting), dribbling. ), receiving and controlling the ball (receiving and controlling the ball), heading the ball (heading), feinting (Rizhardi, 2020).

One of the techniques that football players must possess is the passing technique. The usefulness of this passing technique is to pass the ball to a friend at close range, which helps prepare attacks and create opportunities to score goals in a match. If a football player has good passing skills, then the team's mastery of the game when attacking and winning the game will be even greater (Dellal et al., 2011). The passing technique is an individual technique skill, which every player must master. The passing technique is a basic technique that is very important in a football team because cohesiveness can be established with passing. With good passing, a player will run into open spaces and control the game when building an attacking strategy (Syukur \& Soniawan, 2015). 
Jendral A. Yani Street Lorong Gotong Royong 9/10 Ulu Palembang South Sumatera

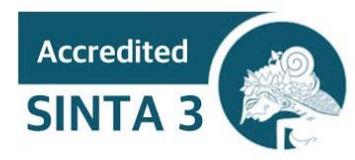

email jurnal: jurnalhon@univpgri-palembang.ac.id situs web: http://www.univpgri-palembang.ac.id

Based on observations and interviews conducted by researchers with several football school coaches who are registered with the PSSI Padang City Association, the Football Academy, the West Sumatera Sports Talent UPTD and UNP Football Club in carrying out an exercise program to improve football passing techniques with the inside of the foot it is necessary improvement and analysis of the movement of the passing technique were carried out. The reality in the field is that there are still many players making passing errors, inaccurate, lack of weight, and quality of passing which results in players often losing the ball, intercepted by opponents so that the team's tactics do not work during matches.

Based on this, the researcher raised this problem in the form of a study entitled "The Football Passing Technique Skills." Referring to the title of the study, the problem of this research is how the skill level of football passing techniques and guides the coach more specifically in analyzing the movements of football passing techniques. The urgency of the findings of this study can be used as a reference and recommendation for academics, coaches and football stakeholders that the passing technique has a function for attacking, defending, and transitioning in achieving the idea of a football game.

\section{METHOD}

This research is descriptive quantitative research. It aims to describe and analyze the results of football passing technique skills. This research was conducted in June 2021. The population in this study were football players U20 years, from the UNP Football Club, totaling 30 people. The sampling technique used in this study was total sampling, so the sample in this study was 30 players from the UNP Football Club.

The instrument used in this study was a football passing ability test (S Afrizal, 2018). The goal is to measure the passing ability of football. The instructions for carrying out the test were (1) Teeste stood with the ball at the start line A, (2) When 
Jendral A. Yani Street Lorong Gotong Royong 9/10 Ulu Palembang South Sumatera

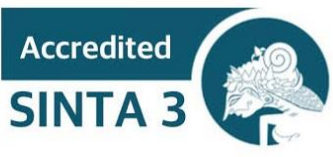

email jurnal: jurnalhon@univpgri-palembang.ac.id situs web: http://www.univpgri-palembang.ac.id

there was a "Yes" signal, Teeste pushed the ball into area B and then passed it towards goal C, (3) The implementation was carried out five repetitions. The test assessments were (1) the ball on target went into the goal, a score of 3 was obtained, (2) if the ball hit the markers/cones, it got a value of 2, (3) if the ball went out of the area, it got a score of 1 . The score taken was a total of 5 repetitions.

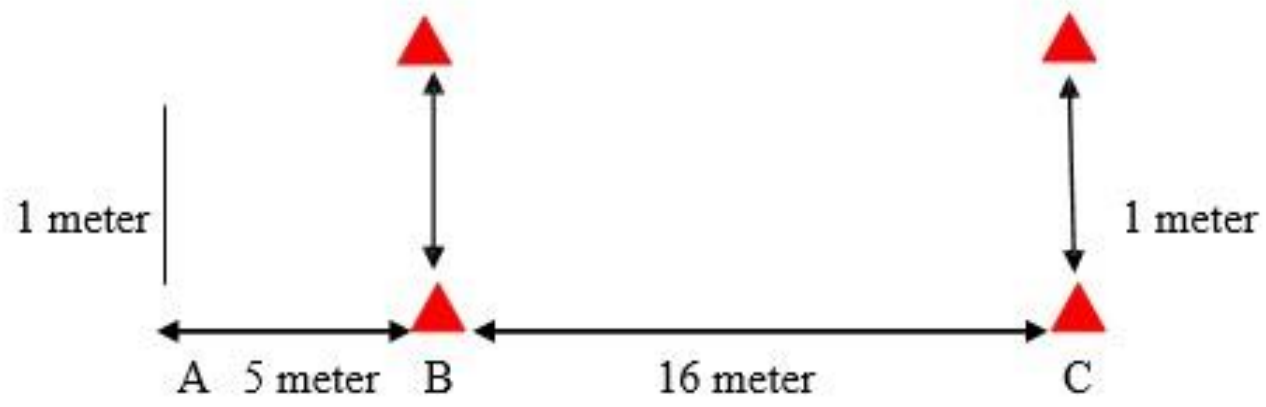

Figure 1. Football Passing Ability Test

The data analysis technique used in this study was the level of classification of the norm of football passing ability test criteria (S Afrizal, 2018).

Table 1. Football Passing Ability Test Norms

\begin{tabular}{cc}
\hline Norms & Categories \\
\hline 11,96 & Excellent \\
$10,40-11,96$ & Good \\
$8,81-10,39$ & Average \\
$7,24-8,80$ & Fair \\
$<7,24$ & Poor \\
\hline
\end{tabular}


Jendral A. Yani Street Lorong Gotong Royong 9/10 Ulu Palembang South Sumatera

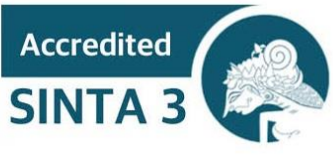

email jurnal: jurnalhon@univpgri-palembang.ac.id situs web: http://www.univpgri-palembang.ac.id

\section{RESULTS AND DISCUSSION}

Based on the implementation of the football passing ability test for UNP Football Club players with a sample of 30 people, with the measurement results obtained the distribution of data as shown in the table below:

Table 2. Football Passing Ability Test Data

\begin{tabular}{ll}
\hline Mean & 10,13 \\
Median & 10,00 \\
Mode & 11,00 \\
S.D & 2,25 \\
Maximum score & 15,00 \\
Minimum score & 6,00 \\
Variant & 5,085 \\
\hline
\end{tabular}

Based on the distribution of the data in the table above, the average value (mean) is 10.13, the mean (median) is 10.00 , the value often appears (mode) is 11.00 , the standard deviation is 2.25 , the maximum score is 15.00 , the minimum score is 6.00 , and the variant is 5.085. Furthermore, the distribution that is arranged based on the test norms that have been analyzed can be seen in the frequency distribution table in the table below:

Table 3. Frequency Distribution of Football Passing Ability

\begin{tabular}{llll}
\hline Interval Class & Criteria & $\begin{array}{l}\text { Frequency } \\
\text { Absolute }\end{array}$ & Relative \\
\hline$>11,96$ & Excellent & 6 & 20.00 \\
$10,40-11,96$ & Good & 7 & 23.33 \\
$8,81-10,39$ & Average & 11 & 36.67 \\
$7,24-8,80$ & Fair & 2 & 6.67 \\
$<7,24$ & Poor & 4 & 13.33 \\
Total & & 30 & 100 \\
\hline
\end{tabular}




\section{OLAHRAGA}

JURALL JUII KEOLDURAQTAA
Jendral A. Yani Street Lorong Gotong Royong 9/10 Ulu Palembang South Sumatera

email jurnal: jurnalhon@univpgri-palembang.ac.id situs web: http://www.univpgri-palembang.ac.id

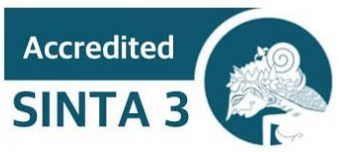

Based on the table above, $6(20.00 \%)$ out of 30 players in this study are in excellent category, 7 players $(23.33 \%)$ are in good category, 11 players $(36.67 \%)$ are in average category, 2 players (6.67\%) are in fair category and 4 players (13.33\%) are in poor category.

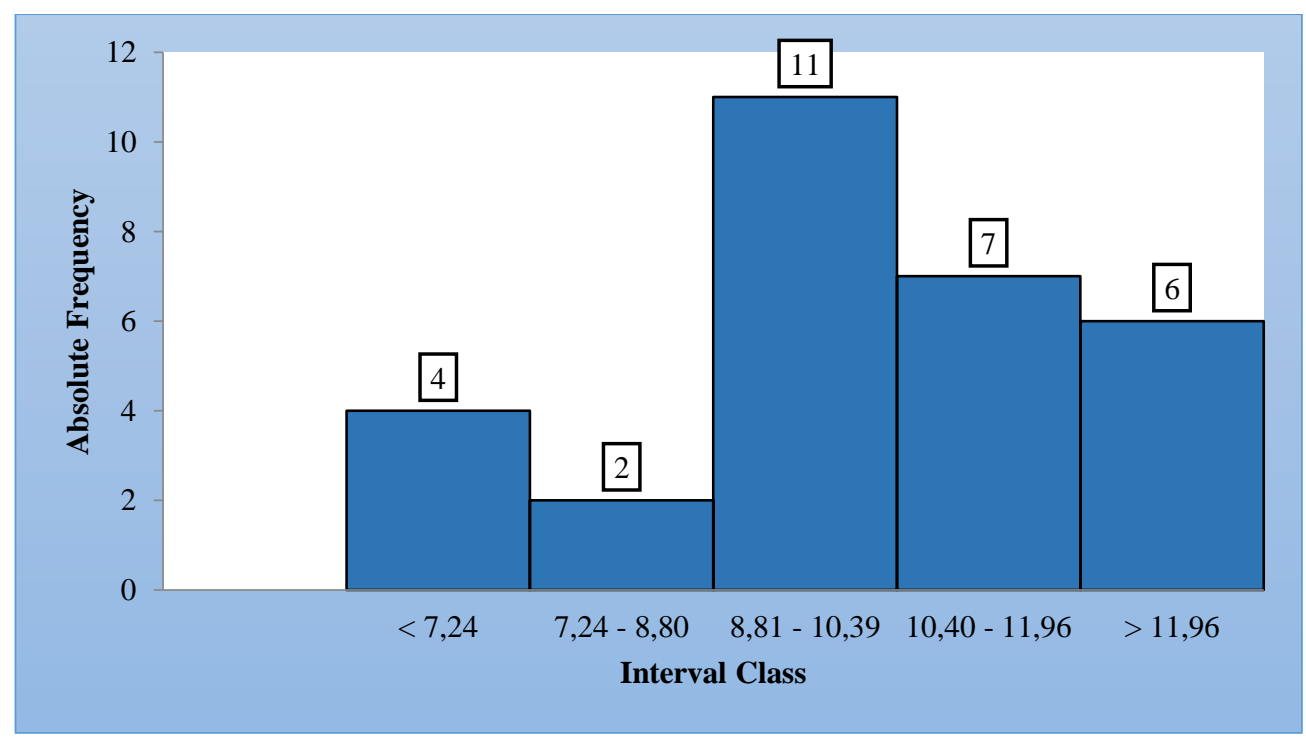

Figure 2. Football Passing Ability Test Graph

\section{Discussion}

This research is a descriptive study that aims to describe and analyze football passing technique skills that were carried out in June 2021. The research data described above are the results of conducting a test of football passing technique ability. The results obtained that 11 out of 30 players who can pass are in the average category.

Based on these results, it shows that the players' ability of the football passing technique needs to be improved to achieve the team's success rate, which depends on cooperation in improving the passing technique along with other technical skills (Hughes et al., 2012). These technical skills complement each other because passing is one technique to score a goal (García López et al., 2013).

\section{6 | Halaman Olahraga Nusantara copyright@Vega Soniawan}




\section{HALAMAN Jendral A. Yani Street Lorong Gotong Royong 9/10 Ulu OLAHRAGA Palembang South Sumatera

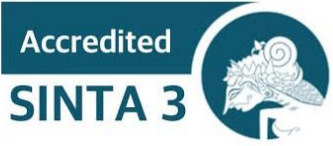

Technical ability is an essential ability that players must have when playing football, either moving with or without the ball (Cahyono \& Sin, 2018). Techniques with the ball include controlling the ball with body parts using feelings (ball feeling), passing the ball, kicking the ball towards the goal (shooting), dribbling, receiving and controlling the ball, heading the ball, feinting, goalkeeper (goalkeeping).

Football players must master the passing techniques because the ability to play techniques supports a player in playing football. The usefulness of this passing technique is to pass the ball to a player at close range, which helps prepare attacks and create opportunities to score goals in a match (Soniawan et al., 2021). If a football player has good passing skills, then the team's mastery of the game when attacking and winning the game will be even greater.

The passing technique is one of the techniques that must be possessed by a player in the game of football. Passing is a basic unit that players must own in working together in a team, depending on the effectiveness and efficiency of attacking a team (Ridwan, M. S, Afrizal. Soniawan, 2020). A prerequisite for accurate passing in association football is that a player perceives the ability, that is, the opportunity to act, from a given situation.

If the mastery of passing technique skills is excellent, it will help to improve the quality of the performance of the player's game such as the player can hold the ball well, the player can control the ball perfectly as desired so that the ball cannot be seized by the opponent and can assist in preparing attacks (Atradinal, \& Sepriani, 2016). Passing is best done using the feet, but other body parts can also be used ( $\mathrm{S} \&$ Soniawan, V, 2021). Thus, passing is an attempt to move the ball from one player to another in a team, for example, by using the foot. Moreover the training methode and the factor of eye-foot coordination must be consider by the coach when training the athlete, because it will affect to the passing accuracy (Prasetyo \& Irawan, 2020) 
Jendral A. Yani Street Lorong Gotong Royong 9/10 Ulu Palembang South Sumatera

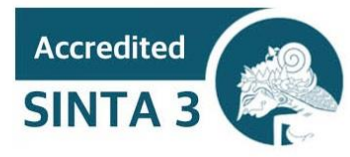

email jurnal: jurnalhon@univpgri-palembang.ac.id situs web: http://www.univpgri-palembang.ac.id

Having accurate passing is a fixed price for a football player. Given that passing is often done in a match, a good coach will start his job by improving the passing ability of his players. The fed ball must be firm, meaning not slow but not too hard (Deswari \& Arwandi, 2019). The importance of a coach in determining the proper method to train football players. Players do not learn the same way as adults, mainly when the learning process includes intellectual and physical activity (Kempe et al., 2014).

Therefore, based on the results of the research obtained, it is expected that coaches and football players always pay attention to and improve football technique skills, especially passing. Because of an excellent passing technique, the process of controlling the ball when attacking, defending, and transitioning to score many goals follows the idea of a football game.

\section{CONCLUSION}

Based on the research and discussion results, it can be concluded that the football passing technique skills of the UNP Football Club players are categorized as average. It is recommended that coaches be able to analyze, develop, and apply appropriate models or forms of training in compiling programs that are following players' abilities. Furthermore, it is suggested for players to practice passing exercises and other techniques to realize their abilities in football games.

\section{ACKNOWLEDGEMENTS}

The researchers would like to thank the Institute for Research and Community Service, Universitas Negeri Padang, which has provided research funding, the football teaching team from the Department of Coaching, Faculty of Sports Science, Universitas Negeri Padang, who has provided advice, input, and support for this research. We also thank the managers, coaches, and players of the UNP Football Club who have facilitated infrastructure and research data collection. 
Vega Soniawan, Yogi Setiawan, Eval Edmizal, Jeki Haryanto, Ikhwanul Arifan, (2022)

Jendral A. Yani Street Lorong Gotong Royong 9/10 Ulu Palembang South Sumatera

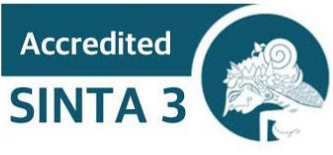

email jurnal: jurnalhon@univpgri-palembang.ac.ic situs web: http://www.univpgri-palembang.ac.id

\section{REFERENCES}

Aguiar, M., Botelho, G., Lago, C., MaçAs, V., \& Sampaio, J. (2012). A review on the effects of soccer small-sided games. Journal of Human Kinetics, 33(1), 103-113. https://doi.org/10.2478/v10078-012-0049-X

Almeida, C. H., Ferreira, A. P., \& Volossovitch, A. (2013). Offensive sequences in youth soccer: Effects of experience and small-sided games. Journal of Human Kinetics, 36(1), 97-106. https://doi.org/10.2478/hukin-2013-0010

Aminudin, A., Sugiyanto, S., \& Liskustyawati, H. (2020). Contribution Leg Muscle Strength, Dynamic Balance and Hip Joint Flexibility to the Accuracy of Football Shooting. Budapest International Research and Critics in Linguistics and Education (BirLE) Journal, 3(2), 912-918. https://doi.org/10.33258/birle.v3i2.985

Anwar, A., Widiastuti, W., \& Setiakarnawijaya, Y. (2019). Football Passing and Control Skills Exercise Model Based on Small Side Games For Ages 12-14 Years. Budapest International Research and Critics in Linguistics and Education (BirLE) Journal, 2(3), 481-493. https://doi.org/10.33258/birle.v2i3.420

Asrul, M., Nugraha, T., \& Kasih, I. (2021). Differences in the Effect of Small Sided Game and Drill Training Methods on Passing Accuracy and V02Max in Football Games in High School Students. Budapest International Research and Critics Institute (BIRCI-Journal): Humanities and Social Sciences, 4(1), 458-464. https://doi.org/10.33258/birci.v4i1.1627

Atradinal, \& Sepriani, R. (2016). Pemulihan Kekuatan Otot Pada Atlet Sepakbola. Jurnal Men, 1(1), 99-105. https://doi.org/https://doi.org/10.24036/jm.v2i2.86

Cahyono, S., \& Sin, T. H. (2018). Kontribusi Daya Ledak Otot Tungkai dan Koordinasi Mata Kaki Terhadap Akurasi Shooting Sepakbola. Patriot, 1(2), 299-305. https://doi.org/https://doi.org/10.24036/patriot.v0i0.47

Dellal, A., Jannault, R., Lopez-Segovia, M., \& Pialoux, V. (2011). Influence of the numbers of players in the heart rate responses of youth soccer players within $2 \mathrm{vs}$. 2, 3 vs. 3 and 4 vs. 4 small-sided games. Journal of Human Kinetics, 28(1), 107114. https://doi.org/10.2478/v10078-011-0027-8 
Vega Soniawan, Yogi Setiawan, Eval Edmizal, Jeki Haryanto, Ikhwanul Arifan, (2022)

Jendral A. Yani Street Lorong Gotong Royong 9/10 Ulu Palembang South Sumatera

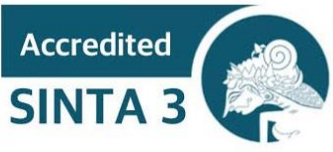

Deswari, I., \& Arwandi, J. (2019). Korelasi Kekuatan Otot Tungkai dan Koordinasi Mata Kaki Terhadap Kemampuan Passing Pemain Sepakbola SSB Putra Wijaya Kota Padang. Jurnal Patriot, 1(1), 151-157. https://doi.org/https://doi.org/10.24036/patriot.v1i1.169

García López, L., González Víllora, S., Gutiérrez, D., Serra, J., Gutiérrez Díaz del Campo, D., \& Serra Olivares, J. (2013). Development and validation of the game performance evaluation tool (GPET) in Soccer. SPORT TK-Revista EuroAmericana de Ciencias Del Deporte, 2(1), 89-99. https://doi.org/10.6018/185791

Gema, A. R., Rumini, \& Soenyoto, T. (2016). Manajemen Kompetisi Sepakbola Sumsel Super League (Ssl) Kota Palembang. Journal of Physical Education and Sport, 5(1), 8-16.

Haryanto, J., \& Welis, W. (2019). Minat Berolahraga pada Kelompok Usia Middle Age. Jurnal Performa Olahraga, 4(02), 214-223.

Hughes, M., Caudrelier, T., James, N., Redwood-Brown, A., Donnelly, I., Kirkbride, A., \& Duschesne, C. (2012). Moneyball and soccer - An analysis of the key performance indicators of elite male soccer players by position. Journal of Human Sport and Exercise, 7(SPECIALISSUE.2), 402-412. https://doi.org/10.4100/jhse.2012.72.06

J. Arwandi, M. Ridwan, R. Irawan, \& Soniawan, V. (2020). Pengaruh Bentuk Latihan Squat Jump Terhadap Kekuatan Shooting Sepakbola Atlet Pro:Direct Academy. Jurnal Menssana, 5(2), 182-190. https://doi.org/https://doi.org/10.24036/MensSana.050220.11

Kempe, M., Vogelbein, M., Memmert, D., \& Nopp, S. (2014). Possession vs. Direct Play: Evaluating Tactical Behavior in Elite Soccer. International Journal of Sports Science, 4(6A), 35-41. https://doi.org/10.5923/s.sports.201401.05

Meylan, C., Cronin, J., Oliver, J., Hughes, M., \& Manson, S. (2014). An evidencebased model of power development in youth soccer. International Journal of Sports Science and Coaching, 9(5), 1241-1264. https://doi.org/10.1260/17479541.9.5.1241

Pandaleke, T., Dlis, F., \& Widiastuti. (2019). The Effect of Balance, Arm Muscle 90 | Halaman Olahraga Nusantara copyright@Vega Soniawan 
Vega Soniawan, Yogi Setiawan, Eval Edmizal, Jeki Haryanto, Ikhwanul Arifan, (2022)

Jendral A. Yani Street Lorong Gotong Royong 9/10 Ulu Palembang South Sumatera

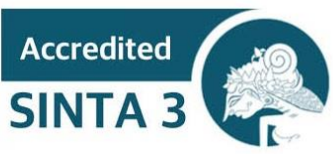

email jurnal: jurnalhon@univpgri-palembang.ac.ic situs web: http://www.univpgri-palembang.ac.id

Strength, and Creativity towards Discus skills on Faculty of Students of Manado State University Science. Britain International of Linguistics Arts and Education (BIoLAE) Journal, 1(2), 160-174. https://doi.org/10.33258/biolae.v1i2.67

Prasetyo, K., \& Irawan, F. A. (2020). The Effect of Exercise Methods and Eye-Foot Coordination on Football Passing Accuracy. Journal of Physical Education and Sports, 9(1), 82-87.

Ridlo, Azi Faiz \& Saifulloh, I. (2018). Pengaruh Metode Latihan Small Sided Game Terhadap Kemampuan Passing-Stopping Permainan Sepakbola. Jurnal Research Physical Education, IX(2), 116-121. http://jurnal.unismabekasi.ac.id/index.php/motion/article/view/1591

Ridwan, M. S, Afrizal. Soniawan, V. (2020). Kekuatan Musculus Abdominalis Dan Kelentukan Pinggang Berhubungan Dengan Kemampuan Heading Pemain Sekolah Sepakbola. Jurnal Sporta Saintika, 5(2), 149-159. https://doi.org/https://doi.org/10.24036/sporta.v5i2.138

Rizhardi, R. (2020). LATIHAN KOLABORATIF DALAM MENINGKATKAN KEMAMPUAN TEKNIK DASAR BERMAIN SEPAKBOLA SISWA. Jurnal Halaman Olahraga Nusantara, 3(I), 9-20. https://doi.org/http://dx.doi.org/10.31851/hon.v3i1.3510

S, A., \& Soniawan, V, . (2021). Development of Football technique Skills Test Instruments for U-17 Players. Jurnal Patriot, 3(March), 71-81. https://doi.org/https://doi.org/10.24036/patriot.v3i1.774

S Afrizal. (2018). Dayaledak Otot Tungkai Dan Kelentukan Berkontribusi Terhadap Akurasi Shooting Sepakbola. Performa Olahraga, 3(02), 6-14. https://doi.org/https://doi.org/10.24036/jpo15019

Soniawan, V,. \& Irawan, R. (2018). Metode Bermain Berpengaruh Terhadap Kemampuan Long Passing Sepakbola. Performa Olahraga, 3(01), 42-49. https://doi.org/10.31227/osf.io/6vgxz

Soniawan, V., Setiawan, Y., \& Edmizal, E. (2021). An Analysis of the Soccer Passing Technique Skills. Proceedings of the 1st International Conference on Sport Sciences, Health and Tourism (ICSSHT 2019), 35(Icssht 2019), 20-23. https://doi.org/https://doi.org/10.2991/ahsr.k.210130.005 
Vega Soniawan, Yogi Setiawan, Eval Edmizal, Jeki Haryanto, Ikhwanul Arifan, (2022)

Jendral A. Yani Street Lorong Gotong Royong 9/10 Ulu Palembang South Sumatera

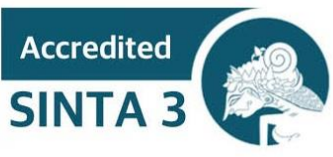

email jurnal: jurnalhon@univpgri-palembang.ac.id situs web: http://www.univpgri-palembang.ac.id

Syukur, A., \& Soniawan, V. (2015). The Effects of Training Methods and Achievement Motivation Toward of Football Passing Skills. Jipes - Journal of Indonesian Physical Education and Sport, 1(2), 73. https://doi.org/10.21009/jies.012.07

Trianda, M., Maidarman, M., Mardela, R., \& Soniawan, V. (2020). ANALISIS TEKNIK SHOOTING PEMAIN SEPAKBOLA SSB SEROJA BUKITTINGGI. Jurnal Patriot, 2(4), 982-990. https://doi.org/https://doi.org/10.24036/patriot.v2i4.687 